\title{
BETWEEN DUBLIN AND SIBERIA: POLAND IN THE NATION NEWSPAPER, 1846
}

\author{
JAN JĘDRZEJEWSKI
}

It has for a long time been something of a critical commonplace among cultural historians and literary scholars alike to see Ireland and Poland as sister nations which, albeit geographically distant, have over the centuries followed similar historical and political trajectories, developed similar patterns of social and cultural life, and generated similar types of mentality. The popular stereotypes of a typical Irishman and a typical Pole - sociable, passionate, generous, patriotic, but at the same time irrational, dogmatic, intolerant, and obsessively preoccupied with ideologies of the past at the expense of pragmatically engaging with the realities of the present - are of course only partly accurate; in fact, it could well be argued that the perception of Poland as the Central-Eastern European equivalent of Ireland, a fervently Catholic nation which clung, during long years of political and cultural oppression, to its faith and its culture in an attempt to preserve its sense of national identity and pride, to eventually emerge, after the First World War, as an independent nation liberating itself from the political dominance of its powerful yet somehow morally inferior eastern neighbour, offers a rather simplistic and superficial interpretation of a much more complex set of historical, sociological, and cultural comparisons that could be made between those two nations.

And yet there were indeed moments in Irish and Polish history, not least during the nineteenth century, when some straightforward historical analogies could indeed justifiably be made, and when the problems facing Irish and Polish societies, the concerns of the Irish and Polish public opinion, and the themes and ideas explored by Irish and Polish thinkers and artists followed similar lines, and possibly - as it is the intention of this paper to demonstrate - influenced each other in a dynamic and creative way.

One such moment was clearly the 1840s - a time during which the social and political debates stimulated by the spirit of Romantic liberalism were paving the way for the outbreak, in 1848, of a pan-European revolutionary movement later referred to, in some parts of the continent, as 'the Spring of Nations' - le printemps des peuples. In Ireland, by far the most significant exponents of this Romantic nationalist ideology were members of the Young Ireland movement - a group of young, middle-class Dublin intellectuals who embraced radical causes of non-sectarian cultural nationalism and political autonomy for Ireland, associating 
themselves with the movement aiming at the repeal of the 1800 Act of Union between Great Britain and Ireland. Led by Charles Gavan Duffy, John Blake Dillon, and Thomas Davis, the Young Irelanders founded, in October 1842, an influential weekly newspaper, the Nation, which promptly became the semiofficial standard-bearer of Irish Romantic nationalism.

It was on 18 April 1846 that the Nation published a poem that was to become one of the most powerful expressions, in mid-nineteenth-century Irish literature, of the tensions between, on the one hand, the Romantic belief in individual freedom and in the values of political liberalism, and, on the other hand, the oppressiveness of the conservative political regimes still in power across most of Europe in the 1840s. 'Siberia', by one of the Nation's most prominent contributors, a typically Romantic poète maudit James Clarence Mangan, remains to this day a powerful expression of outrage at the physical as well as psychological cruelty of the repressive regime of the Tsarist Empire:

In Siberia's wastes

The Ice-wind's breath

Woundeth like the toothèd steel.

Lost Siberia doth reveal

Only blight and death.

Blight and death alone.

No Summer shines.

Night is interblent with Day.

In Siberia's wastes alway

The blood blackens, the heart pines.

In Siberia's wastes

No tears are shed,

For they freeze within the brain.

Nought is felt but dullest pain,

Pain acute, yet dead.

Pain as in a dream,

When years go by

Funeral-paced, yet fugitive,

When man lives, and doth not live,

Doth not live - nor die.

In Siberia's wastes

Are sands and rocks.

Nothing blooms of green or soft,

But the snowpeaks rise aloft

And the gaunt ice-blocks.

And the exile there

Is one with those; 
They are part, and he is part,

For the sands are in his heart,

And the killing snows.

Therefore, in those wastes

None curse the Czar.

Each man's tongue is cloven by

The North Blast, who heweth nigh

With sharp scymitar.

And such doom each drees,

Till, hunger-gnawn,

And cold-slain, he at length sinks there,

Yet scarce more a corpse than ere

His last breath was drawn.

(Chuto, Holazpfel \& Shannon-Mangan 1997: 157-8)

To a Polish reader, Mangan's poem sounds peculiarly familiar in terms of its theme and imagery: the myth of exile into the depths of Siberia, a standard form of repression used by the Tsarist regime as a way of silencing dissident voices and eradicating radical movements among ethnic Russians (for example, in the aftermath of the Decembrist revolt of 1825) as well as suppressing nationalist movements in non-Russian parts of the Empire - most notably, in the context of Polish history, following the November uprising of 1830-1831. The images of the loneliness and deprivation, psychological as well as physical, suffered by exiles in the cold and seemingly endless wastes of Siberia, are readily evocative of similar images scattered throughout Polish Romantic poetry; perhaps the best parallel can be found in Juliusz Słowacki's powerful tale of Anhelli (1838), an epic prose poem, in Biblical idiom, using the fate of Polish exiles in Siberia as a basis for a soul-searching exploration of the dilemmas of post-1831 Polish emigrés, not only in Russia, but also - and indeed primarily - in Western Europe:

And so the Shaman and Anhelli made their pilgrimage through the sorrowful country and over the desolate roads and under the roaring forests of Siberia, meeting men who suffered, and comforting them.

(Słowacki 1930: 38)

Given the prominence of the motif of exile into Siberia in Poland's national mythology, it comes as a major surprise to a Polish reader to realise that Anglophone critics have tended to interpret Mangan's poem in purely metaphorical terms, ignoring the direct references to Siberia and the Czar, and concentrating instead on the motifs of hunger, blight and death, perceived as topical references to the Great Famine, triggered by the potato blight, whose first signs began to appear in Ireland in September 1845, i.e. seven months before the publication of the poem. Thus, for example, Robert Welch argues that "the bleakness in 'Siberia' is a profound metaphor for the state of Ireland in 1846, and 
for the state of Mangan's own personal condition” (Welch 1980: 105); he goes on to say that the image of the exile being unable to speak and curse the Czar

expresses at once Mangan's awareness of the way things were in the country at the time, and his sense of futility about them, for political reasons; but it also shows the psychological difficulty Mangan had about expressing himself in his own voice. National disaster and personal frustration, political and creative, are fused in the metaphor of Siberia. The metaphor is a manoeuvre, almost certainly unconscious, to enable him to deal with the reality of Ireland in 1846, and his own response to it.

(Welch 1980: 106)

Melissa Fegan reiterates the same broad point, associating the context of the Famine with Mangan's own sense of personal doom, and arguing that "Siberia is Famine Ireland, recognized by Mangan as what always waited for him in the future, a wasteland of dull pain and death" (Fegan 2002: 192). Neither critic appears to recognise that the poem was written and published at a very early stage of the Famine, before the critical second failure crop of the summer and autumn of 1846, and at the time when the agrarian policies of the then Prime Minister, Sir Robert Peel, were generally felt to offer a reasonable level of assistance and support to those in need of emergency food supplies.

Perhaps the most illuminating of recent interpretations of 'Siberia' comes from Matthew Campbell, whose initial acceptance of the standard Hibernocentric reading of the poem

Potato blight was the cause of Famine, and blight here brings death as the landscape is transformed into a featureless and dark place, imbued with hunger and cold. Yet the overarching conceit of the poem is to write of an eastern place, far away from the dying west in which the poet seemed to live. In metaphor, the poem performs a sort of translation of the Celtic into the Oriental, something with which Mangan often played in his Oriental translations, forgeries and parodies.

(Campbell 2002: 451)

is undercut by his perceptive analysis of the way in which the dark vision of the poem is conveyed through his unorthodox use of language:

'Siberia' appears to enable the geographical dislocation in the metaphor to perform what many metaphors of insurrection find they have to do: secrete its message within the metaphors of a poem which appears to be located in a foreign place. Except here any rebellious message appears to hold out little consolation: the banished exile, along with all in Siberia, cannot curse the Czar. The diction of the poem is filled full of English archaisms - Wounded, toothèd, doth, heweth nigh - and even Scots, 'drees'. Mangan seems to work against the metaphor's dislocation, re-integrating English and thus effecting the obliteration of difference. 'Siberia' is tugged away from and then back into the literary 
language from which it might be expected to show a profound exile. Almost despite the metaphoric translation of the poem itself, the languages of Britain English, Hiberno-English, Scots - like night and day in the poem appear to be 'interblent'. ... 'Siberia' looks like an act of union.

(Campbell 2002: 451)

Campbell's reading captures the logical inconsistency in the conventional interpretation of 'Siberia' as an expression of the tragedy of the Famine, but it stops short of identifying the source of that inconsistency: the difficulty with the reading of the poem as a metaphor of the fate of the Irish peasant in the spring of 1846 is not that Mangan fails to find an adequate poetic form to convey his message - it is, rather, that the initial premise on which the whole argument is based is problematic. And if the refusal to consider the seemingly banal possibility that the poem might actually be about what it explicitly announces it is about - the fate of unnamed, desperate, lonely exiles in Siberia - clearly generates readings which are either plainly irrational or self-contradictory (not to mention historically inaccurate), then maybe it is time to reconsider the validity of the Hibernocentric approach to the poem, to revisit the underlying assumptions about what is supposedly its essentially metaphorical structure, and to see 'Siberia', for a change, on a more direct, literal level, and thus in its Eastern European, and indeed Slavonic, context.

Considered alongside the broad spectrum of James Clarence Mangan's poetic œuvre, 'Siberia' stands out as one of his most unusual creations, not least because it is the only one of his poems to use a Slavonic setting for a text that was presented to the public as an original work, and not - as was the case with the great majority of his poems - as a translation or an adaptation of an earlier text, or indeed an imitation or a pastiche of a poem from another literary and cultural tradition. ${ }^{1}$ Mangan had very occasionally used Slavonic motifs before writing 'Siberia', and he would use them on a few occasions again later in his career, but their function in his poetry is almost invariably merely ornamental rather than thematic or topical: references to Bohemia or Serbia (or, as Mangan would have it, Servia) tend to be used as little more than touches of local colour designed to create a sense of exotic authenticity in poems which are, essentially, conventional high Romantic tales of love, hatred, sin, revenge, war and death. Thus, for example, the originally Czech tale of 'The Marvellous Bell - A Popular Legend',

\footnotetext{
${ }^{1}$ A recent discovery of a possible source of 'Siberia' - a poem 'Siberien' by a minor German Romantic poet, Ernst Ortlepp - strengthens the case for an internationalist rather than Hibernocentric reading of the poem; at the same time, the fact that Ortlepp's influence remained, rather uncharacteristically, unacknowledged by Mangan seems to indicate the Irish poet's wish to present 'Siberia' as a commentary on current political events in Europe, and not as a work of historical (and indeed antiquarian) rather than contemporary significance: Ortlepp's 'Siberien' had been written in the aftermath of the 1830 November rising in Poland. I am grateful to Dr Katarzyna Gmerek for drawing my attention to this important detail.
} 
and the originally Serbian poem of 'The Brothers and Sister', adapted, via the German, from, respectively, Karel Sudimir Schneider and Dositej Obradović, do not carry much significance that could be associated directly with their Slavonic origin. Even where the Slavonic context does carry some form of political subtext - as in 'Prince Kazink and the Vaivodes', adapted, again via the German, from an anonymous Serbian poem - the motif of national struggle against foreign (in this case Hungarian) domination

And, long years, till Dendrink's walls grew grey,
Men rejoiced in that bright Day of Blood,
And the Night of Wine that crowned the Day,
And gave Servia back her Nationhood.

(Chuto et al. 1997: 249)

is invoked in the context of a story which is set in a distant, indeed near-legendary past far too firmly to signify anything beyond a conventional post-Byronic sense of Romantic solidarity with the causes of the oppressed and the persecuted.

Interestingly, and somewhat surprisingly perhaps, among Mangan's 'Lays of Many Lands' there are no poems set in Poland, or based on Polish originals this may well be a consequence of the fact that Mangan worked primarily from texts by German poets and translators, whose interest in Slavonic poetry and folklore would have been more likely to focus on the heritage of the nations of the Habsburg Empire. This is, however, not to say that his poetry does not include occasional references to Poland or Poles - and as it happens, they are, in many ways, rather more telling than the conventional references to other Slavonic countries discussed above. Two poems which are worth considering in this respect are 'The Domiciliary Visit' - effectively, a micro-drama possibly translated from the French - and 'Freedom and Right', an adaptation of 'Die Freiheit! Das Recht!' by the German poet Ferdinand Freiligrath.

In the former poem, set in Paris during the reign of Louis-Philippe, and describing the scene of a police search in the room of a man suspected of revolutionary activity, one of the characters, referred to as an Officer of the Gendarmerie, finds a book - 'treatise on the Poles'; despite its innocent owner's assurances that it is about 'The South / And North Poles only', the Officer offers his own interpretation of events:

\section{Rebel!}

How dare you open your gamin mouth?

Your explanations treble

Your guilt. South Pole and North! To what

Owes Earth its revolutions,

If not to these, you leveller-flat

Of thrones and institutions?

(Chuto et al. 1997: 153-4) 
A rather similar association of Polishness with the spirit of rebelliousness - or rather, in a more positive vein, Romantic struggle against oppression and persecution - is conveyed in the opening stanza of Mangan's version of Freiligrath's poem:

O! think not the Twain have gone down to their graves!

O! Say not that Mankind should basely despair.

Because Earth is yet trodden by tyrants and slaves,

And the sighs of the Noble are spent on the air!

Oh, no! though the Pole, from the swamps of the North,

Sees trampled in shreds the bright banner he bore;

Though Italy's heroes in frenzy pour forth

The rich blood of their hearts on the dark dungeon-floor,

Still live -

Ever live in their might

Both Freedom and Right!

(ib., 154)

The interesting thing here is that the lines describing the Pole watching the destruction of his bright banner of freedom and the suffering of the imprisoned Italian heroes are absent from the German original: Mangan's modification of the text not only adds to the English-language version of the poem a topical reference to current European politics, but also conveys a clear suggestion that the causes of the independence of Poland and of the unification and democratisation of Italy are not merely representative, but indeed symbolic of the broader, pan-European movement of Romantic liberalism and nationalism.

Is there, however, a connection between those two poems of Mangan's and 'Siberia'? How relevant are the two isolated, local references to Poland to a poem which focuses on the universal, rather than particularised, experience of oppression and suffering? In fact, the link is very close: both 'The Domiciliary Visit' and 'Freedom and Right' were published in the Nation on 4 April 1846, just two weeks before the publication, in the same newspaper, of 'Siberia'. Taken together, the three poems clearly demonstrate that Mangan's attention was, in April 1846, clearly focused on the political affairs of Poland and Russia, and in particular on matters relating to revolutionary movements in Poland and their suppression by the tyranny of the imperial regimes against which those movements were directed. The fact that Mangan had never before demonstrated any particular interest in Polish affairs suggests that his sudden recognition of the central place of Polish nationalism in the broad spectrum of the Romantic liberalism of the 1840s must have been triggered by some specific factors which would have made the situation in Central and Eastern Europe both familiar and significant enough to the readers of the Nation to warrant the introduction of references to Poland and Siberia to a number of texts published in the newspaper at the time. 
A careful study of the Nation for the early months of 1846 reveals what readers familiar with the history of Poland in the mid-nineteenth century will by now have guessed: the event which triggered Mangan's new interest in Polish politics was the short-lived insurrection which took place, in late February 1846, primarily in the then Free City of Cracow, and to a much lesser extent in the former Polish - and at that point, Austrian - province of Galicia, south and east of Cracow; there were also isolated incidents in Polish lands under Russian and Prussian rule. The Cracow revolution, led by young radicals such as Edmund Dembowski and Jan Tyssowski, may now, with the benefit of hindsight, appear to have been little more than a rather feeble, misguided, and naïvely optimistic attempt to organise a national uprising against the three powers which had partitioned the old Polish Commonwealth in the late eighteenth century; at the time, however, it not only received extensive coverage in the European press, but also acquired an almost symbolic significance. For a liberal newspaper like the Nation, the Cracow revolutionaries became standard-bearers for the international cause of political freedom, a cause whose manifestation in Poland in 1846 was worth not only reporting on, but indeed celebrating and - after the collapse of the revolution and the subsequent annexation of the Free City of Cracow by the Habsburg Empire - mourning and commemorating.

The Nation's first reports on the events in Poland appeared on 14 March; though by modern standards significantly out of date (the revolution was effectively over by 4 March), they reflected the excitement with which news from Cracow was greeted in the liberal circles of Western Europe. The revolution was judged significant enough to become the first item both in the newspaper's foreign news section and in its editorial column: the week's leading article, entitled 'The March of Freedom' stressed the international context of the events in Poland, and in particular the potential impact that they might generate across Europe:

The Poles are again in arms. The true, fiery, resolute, unconquerable Poles! A great city and several fortresses are in their possession; they have repulsed an Austrian brigade, and captured a provincial treasury and an Imperial magazine of arms and ammunition.

God, in his mercy, guard and direct them! May their counsels be wise and their arms invincible, till no foe can be seen from Danube to the Dwina.

If virtue and suffering, and the justice of a cause that cried out to Heaven for vengeance, might secure their triumph, no foe could stand against them. But their enemies are powerful and merciless, and justice is not a shield against strength. The vultures are already gathering round them, as round a prey. Russia, with countless hordes of Cossacks and Muscovites, (the Goths and Vandals of our day,) drawn from the widest empire on the earth. Austria, with the diabolical strength of a despotism that centuries have trained and perfected into an infernal machine of tyranny. Prussia, a kingdom of soldiers, drilled in mechanical 
obedience, and wielded by no incompetent hand. Oh! the odds are fearful; at once an avalanche of brute force, and an iron net of diplomacy.

But, then, are they not "twenty millions," and fighting to free their dear land from the foreigner? Whatever be the issue, there will be heroic courage and devotion; and the terrible "faucheurs" (or scythes) of the Poles will cut deep into the slave ranks of the Northern Despots.

And if they can hold their guard but for three months, surely they must triumph. Mankind will not look on another Russian butchery in silence -

"It is not in man or in Heaven

To let tyranny triumph again.”

America would send them money and arms; or let her name be accursed, and the title she courts of "Friend of Liberty" be denied her for ever.

France would help them in spite of her own cunning tyrant. Chivalrous, gallant, glorious France would send them men fit to lead their battalions, and guide their native force and enthusiasm by the light of experience and science.

Italy could do more - she could employ one of their enemies. If Mazzini be a man, not a quack and a pretender, he will strike at the throat of the Austrian, and find work for him nearer home; and so his glorious Italy may rise again from the torpor of provincialism to be a kingdom among the kingdoms.

And the daring Circassians, are they not politic as well as bold, and will they not know the hour of their enemy's weakness? With Poland in his front, and in his rear

“The lightening Cherkesses, the thundering Cherkesses,"

Nicholas may find his enormous armies (which happily are not absolute machines, inasmuch as they have to be paid and fed) break with their own unwieldy weight.

Hungary, too, will have the chance for which she longs, and with God's help may use it nobly.

Oh! if this true Holy Alliance of Nations grow up, Poland will have risen to some purpose - to the noblest purpose that Europe has yet seen accomplished under the sun.

Our dear sister Belgium has already leaders in their ranks - leaders who learned their skill and their love of freedom in a triumphant struggle against the strangers who oppressed their native land.

And Ireland - God pity her, she can only give them prayers. But she prays from the bottom of her heavy heart, that the pike and the scythe (the national weapons of Poland, which guarded Warsaw as faithfully as Limerick) may fall like the sword of the avenging Angel on all who resist them. And she blesses the faithful Priests and Monks who have flung themselves into the ranks of the people, prepared to die in defence of the persecuted faith and proscribed nationality of Poland.

(Nation, 14 March 1846: 344)

In subsequent weeks, it became clear that the hopes of the editors of the Nation proved to be as idealistic and naïve as those of the Cracow insurgents: on 21 
March, the paper reported the capture of Cracow by the three 'protecting powers', while the following week, on 28 March, having noted the suppression of the revolution in Galicia, it published another major article expressing its support for the Polish cause, this time entitled 'Gasping Freedom':

Not a voice from Poland, or for her. Stilled Europe listens till its murderous work is done - listens for her death-rattle; and Ireland gazes, as into the agonised face of a beloved sister, to know if she be indeed dead.

But, no - thank Freedom's God - there is a soul in Slavonia still. Her priests are not all martyred - her youths are not all in chains - the heads of her nobles are not all bought - her holy scythe blades are not all broken - "La nationalité Polonaise ne perira pas."

No! never, while a true Pole lives in rebel freedom on the Carpathian hills; never, while a faucheur remains to mow a tyrant down, shall we despair of Poland. Austria may halloo her traitorous serfs, Russia her Ukraine hordes, France her spies; but as surely as there is a God in Heaven, shall Poland yet be free, from the Vistula to the Dwina.

Then, woe to her tyrants! Woe to them who blasphemed Heaven, and defaced earth, in the "Holy Alliance" - to England, Russia, Austria, Prussia, and to another - the perpetuator of that tyrant compact and her own prostitution - France.

Once we gloried in the land of July, in her martyrs, in her tricolor. Once we believed in her boasted mission, and envied the great champion of Freedom her championdom. Now enslaved, Polandised as we are, we would not change our honest nothingness for her mighty infamy. Still she can do one thing and leave the memory of her dead brave dishonoured - she can take down that tricolour she has disgraced; bury it again; it was pure and holy in its grave.

She might have freed Italy from the Austrian - she did nothing. She might have given Nationality to Poland in '31, and avenged the crime of St. Helena on the land of Alexander. She "opened subscriptions!" Again is the victim of Tilsit and Vienna in arms for "national existence;" and what has France done this time?

Hear it, Earth and Heaven too - hear the infamy of France!

She set spies upon the Exiled Poles.

Spies to dog and track the patriot - to pry into the struggles of his heart - to note it seeking to mix its blood with the blood of its own land; spies to map the exile's footsteps, that the tyrants of his country might pounce upon his homeward track, and drag him to an useless gallows. This did France, and on whom? On the sons of that land which she sold at Tilsit - on the men who fought by her side in a hundred fields - who were the enemies of her enemies - nay, who avenged her Republic, her Empire, her conquest, her disgrace, when, before Warsaw's walls, they cut to pieces that same "Prince Albert's cavalry" which formed the advanced guard of the Allied invasion. Retribution, friendship, vengeance - France has forgotten all - become a Muscovite bloodhound - an Austrian scout.

When exiled Mazzini worked for Italian freedom - when "perfidious England" broke open his letters, and effected the butchery of the Bandieras - then France declaimed - then M. Guizot lauded the Post-office conscience of postrevolutionary France. Then was England “perfidious” - who is perfidious now? 
France!

Shame - eternal, undying shame, upon her and upon her sons, the doers and permitters of this crime. Degraded, fallen, despicable are they, unless they rouse like men, and avenge the outraged honour of France, and the still more outraged liberty of Poland. They have this chance, none other.

... But when English, French, Russian, and Austrian robbers arm, with common intent, at honest men's throats, what should honest men do?

Combine.

Combine in a "Holy Alliance" for Freedom - for common National existence - combine to shake the despotism off the earth, and to give vitality to European existence. Combine to strike at once and dismay the robbers of Nationality - to strike in Poland and in Italy at once. To strike at once on the Sutlej, on the Oregon, and wherever else tyranny triumphs.

(ib., 28 March 1846: 377)

The sheer passion of the Nation's condemnation of the failure of the regime of Louis-Philippe to live up to the ideals of the July revolution of 1830, and to the image of France as the champion of liberal causes across Europe, clearly influenced Mangan's perception of the country as an oppressive police state, triggering his publication, in the following week, of 'The Domiciliary Visit'. At the same time, the article's explicit association of the national cause of Poland with that of the unity and independence of Italy, and the identification of the two countries as the two key arenas in which liberal Europe's battle against despotism and tyranny should be fought (the tone of the article is nothing if not explicitly revolutionary), account for the prominence given by Mangan, again only a week later, to the images of exile and imprisonment suffered by Polish and Italian insurgents in his version of Freiligrath's 'Freedom and Right'.

The interest in Polish affairs generated, in the circles of the Young Irelanders, by the events in Cracow was not limited to reporting and commenting on current events: on 28 March and 4 April, the Nation published two 'Sketches of Polish History', focusing, in a characteristically Romantic fashion, on two dramatic moments in Poland's past - the first, on the reign of the lateseventeenth-century king John Sobieski, and his dramatic role in the defence of Vienna against the Ottoman army in 1683, and the second, on the partitions of Poland, the insurrection of 1794, and the eventual demise of Poland's independent statehood in 1795. The tone of the sketches, again too long to be quoted here, is again symptomatic of the unashamedly Romantic perception of history: the story of the last few years of Poland's independence is presented in terms of the struggle between the forces of good and evil personified, respectively, in the insurrection leader Thaddeus Kosciusko (sic!) and Poland's last king Stanislaus Poniatowski.

At the same time, their unqualified support for the Polish insurgents and their own Romantic sensibilities notwithstanding, the editors of the Nation 
remained realistic enough to appreciate that drawing too easy parallels between the political circumstances of Ireland and Poland belied the real nature of the political and cultural situation of the two countries. Taking issue with the Catholic magazine the Tablet, which criticised the Cracow rebels for 'rashness, headstrong impudence, ungovernable impetuosity', they noted, on 4 April, the radical differences between their own circumstances and those of their Polish counterparts:

The Tablet prefers our Irish moral-force agitation to the Polish conspiracies and outbreaks - and he is right: the circumstances of the two countries differ widely: here we have no such intolerable tyranny as that under which Poland groans: here public discussion and political agitation are still possible; the Press is not yet silenced: we need here no secret conspiracy, but may openly and avowedly unite in a grand national constitutional conspiracy, (such as that for which the Repealers were prosecuted, and which is still spreading and strengthening itself on every side,) which enables us to march right to our goal in broad daylight, telling all the world what we are to do, and how we mean to do it. This is well: but while we congratulate ourselves upon our own superior resources, let us not blame the Poles that they have once more tried their own way of shaking off their oppressors. Let us pray for their success next time, and acknowledge that any way is better than none.

(ib., 4 April 1846: 393)

In subsequent weeks, as the events of the Cracow revolution were receding into the past, the readers of the Nation were offered extensive coverage of events triggered by the insurrection, and of the treatment of the insurgents by the governments of the partitioning powers. It was clearly a report on recent developments in Russian Poland, published on 11 April that provided the immediate inspiration for the publication, the following week, of Mangan's 'Siberia':

The leaders of the insurrectionary movement at Siedlec, near Warsaw, have already received their punishment. Potocki has been hanged at Siedlec; Kocishevski and Zarski have been hanged at Warsaw; Dobrytsh and Ruprecht, sentenced to be hanged, had their lives spared, but are degraded from their rank, and condemned to exile and hard labour in Siberia; Mirezki and Deskur were made to pass under the gallows, and sent to Siberia to be kept at hard labour.

(ib., 11 April 1846: 413)

This focus on the repressive measures adopted against Polish insurgents under the Tsarist regime was not entirely coincidental: the liberal circles of Western Europe had for a number of years seen imperial Russia, ruled by Nicholas I, known as gendarme de l'Europe, as an autocratic state imposing its repressive policies not only on political dissidents, but also on members of national and religious 
minorities. This particular perception of imperial Russia had in the mid-1840s received a major boost as a result of a major international controversy caused by the arrival in Paris, in 1845, of a Makryna Mieczysławska, an impostor who claimed to have suffered, as Abbess of a Uniate convent in Minsk, seven years of persecution and torture for her loyalty to the Holy See. The notoriety of Mieczysławska, who managed to command a significant amount of support among the Polish emigré community in France, did in fact have a major impact on the perception of Tsarist Russia as far away as Ireland: the Nation itself had in fact referred to the fate of Mieczysławska and her companions in an editorial on 3 January 1846, while its front page on 14 February carried, at its very top, an advertisement announcing the publication of a full-length account of the story of The Nuns of Minsk, compiled from Mieczysławska's depositions to a Papal commission organised to investigate her allegations. Whether or not Mangan was directly familiar with that particular publication, he would certainly have been aware of the Mieczysławska story, and it would have informed his response to further revelations about the repressive policies of the Russian imperial regime in the aftermath of the events of February and March 1846.

The story of the Cracow revolution of 1846 closes with the end of the Free City of Cracow, annexed by Austria in November that year. This event, marking the end of any form of semi-independent Polish statehood in the nineteenth century, was again duly noted by the Nation, which described it, in an article on 'Cracow' published on 28 November, as "the annihilation of a memory - the fall of a proud image in which the sad exile loved to trace the glory and the chivalry that are gone”. There is, in the Nation's elegiac tone, an echo of the post-Treaty of Limerick poems by Aogán Ó Rathaille, but this initial mood of melancholy resignation promptly gives way to an analysis of the broader European causes of the loss of the independence of Cracow, stressing not only the decisive political and military role of the three partitioning powers, but also the indifference to the Polish cause, or indeed tacit collusion with the aggressors, on the part of the supposedly enlightened, but ultimately reactionary, governments of France and England:

No! Before the Almighty God and the world, the dismemberment of Poland and its consequence - the annihilation of Cracovia - stands as the conspiracy of European imperialism against the great principle of nationality.

A foul conspiracy, which, having reached its climax, is nearest its fall. The "public faith," of which men cant by the hour, is now only harmless when it is a farce. The Treaty of Vienna and other acts of consolidation must be broken; the nationalities of Europe must spring into existence again; for God does not manage the world by a protocol or an Act of Parliament.

(ib., 28 November 1846: 121) 
In the year's final issue, on 26 December, the Nation goes one step further, hinting at the possibility that the annexation of Cracow might lead to some form of pan-European revolution:

Yes: it is a death blow to the Treaty of Vienna, and is so regarded all over Europe. Once before, indeed, the treaty was set at nought when Belgium arose sixteen years ago, and vowed that red tape should tie her no longer to the chariot of a Dutch master. But now, by one of the high contracting parties this notable treaty is signally and contumeliously violated; and morally speaking, the treaty is at an end.

There is high excitement in Italy, from the Maritime Alps to the Tiber; and if France but give the hint, before winter is over, Alp and Appenine will be blazing with signal fires, and the iron crown may once more encircle an Italian head.

But in Paris and London much protocolling goes forward; for Russia has indicated an intention of "annexing" the Grand Duchy of Warsaw (now the "Kingdom of Poland"), which, though subject to the Russian crown, was established as a separate kingdom by the same Treaty of Vienna. Who will have the next blow at the condemned Treaty? He is a skilful prophet who can foretell what will come of this Cracow business within twelve months.

(ib., 26 December 1846: 185)

The Nation's writer was obviously not too wide of the mark: within fourteen months of the publication of those words, the February revolution in Paris forced the abdication of Louis-Philippe and the proclamation of the Second Republic, marking the beginning of what was arguably the most eventful year in the political history of Europe between the fall of Napoleon and the beginning of the First World War.

What does all of this, however, say about the nature of the relationship between Ireland and Poland? The history of the events of 1846 in Poland, and of their perception by the liberal nationalist circles of Dublin, centred around the Young Ireland movement and the Nation newspaper, reveals both the differences between the political, social, and cultural circumstances of the two countries and the similarity of some of their national myths and ideologies. What seems particularly striking, and perhaps rather sobering given some of the traditional perceptions of the two countries and their histories, is that facile parallels based on sentimentalised images of suffering and persecution are not always factually accurate: the conditions of political and cultural debate in nineteenth-century Ireland, conducted in the context of a fundamentally democratic and liberal political system, were radically different from the situation which obtained in the Polish lands, divided between three separate jurisdictions and governed by three essentially autocratic regimes. Where the parallels do exist, they have a peculiarly international and pan-European, rather than specifically Hiberno-Polish or Polono-Irish, flavour: the Young Irelanders and their associates, such as James Clarence Mangan, and their Polish counterparts, such as the leaders of the 1846 
revolution in Cracow, appear to have shared a vision of the future based essentially on the Romantic ideals of liberalism and democracy; their nationalism was outward-looking, progressive, and internationalist in outlook rather than - as has often been the case in more modern times - conservative and self-celebratory, if not downright xenophobic. A comparative look at Ireland and Poland in 1846 demonstrates that the national mythologies of Ireland and Poland could do with some rewriting - and a reinterpretation of Mangan's 'Siberia' away from Hibernocentrism and towards a more universal, international perspective, might be a good place to start.

University of Ulster, Northern Ireland

\section{References}

Campbell, M., 2002, 'Poetry in the Four Nations', in: Cronin, R., Chapman, A., Harrison, A. H., eds., A Companion to Victorian Poetry, Oxford: Blackwell, 438-56.

Chuto, J., Holazpfel, R.P., \& E. Shannon-Mangan, eds., 1997, The Collected Works of James Clarence Mangan: Poems: 1845-1847, Dublin: Irish Academic Press.

Fegan, M., 2002, Literature and the Irish Famine, 1845-1919, Oxford: Oxford University Press.

Slowacki, J., tr. D. P. Radin, 1930, Anhelli (1838), London: Allen \& Unwin.

Welch, R., 1980, Irish Poetry from Moore to Yeats, Gerrards Cross: Colin Smythe. 